\title{
Disguised Foreign Controlled Companies and the Facilitation of Transnational Criminal Activities in Thailand
}

\author{
Srisombat Chokprajakchat ${ }^{1}$, Wanaporn Techagaisiyavanit ${ }^{1,{ }^{*}}$, Tongyai lyavarakul ${ }^{2}$, \\ SiripornYamnill ${ }^{1}$, Theerat Bunnag ${ }^{3}$ and Tunlawat Narongsak ${ }^{4}$
}

${ }^{1}$ Faculty of Social Sciences and Humanities, Mahidol University, Thailand

${ }^{2}$ Graduate School of Development Economics, National Institute of Development Administration, Thailand

${ }^{3}$ Court of Justice, Thailand

${ }^{4}$ Royal Thai Police, Thailand

\begin{abstract}
The primary objectives of the study are to examine the role of a business using Thai nationals as nominee shareholders in foreign-controlled companies in the facilitation of the transnational criminal groups' activities in the tourist destinations, and their social and economic impacts on the country. Nominee shareholder appointment in a legal entity has commonly been recognized as one of the techniques employed by criminal groups to launder and obscure the ownership of their illegal assets. However, this study points out that this type of company also performs other functions in providing resources and a platform for criminal groups to further their goals. The study used mixed methods by gathering qualitative data through conducting in-depth interviews and focus groups with 55 participants from relevant government agencies and private sectors, and by gathering quantitative data through conducting public surveys consisting of 1,160 participants from six provinces across five different regions in Thailand. The study concluded that there is a strong need for the country to improve monitoring mechanisms through legal changes, and collaborations among public, private and civil society as the practice of nominee shareholder appointment, although perceived as a normal practice in the global field of business, such a practice can invite unintended consequences, which can be a serious cause of concern due to the links with illegal activities operated under the umbrella of transnational organized crime.
\end{abstract}

Keywords: Transnational criminal activity, nominee shareholder, Thailand, transnational crime facilitator, Foreign Business Act.

\section{INTRODUCTION}

Nominee shareholders or "straw men" have been identified as a key vulnerability for the infiltration of organized criminal groups in the legitimate economy as they help protect and conceal identities of the beneficial owners (Financial Action Task Force 2018: 6). Common patterns found in several studies is the use of legal persons to launder money and illegal assets (Kruisbergen et al. 2015; Savona and Ricardi 2015; Murray 2013; Organization for Economic Co-operation and Development 2001). Others included corruption, improper insider dealings and illegal tax practices (Organization for Economic Co-operation and Development 2001). These studies portrayed how legal entities, particularly those in the service sector, could become a main actor in the criminal networks by serving as a venue for reinvesting crime proceeds as a strategy to conceal their operations from criminal prosecution. Nonetheless, the role of this type of legal entities as mere facilitators in providing resources has not yet been much explored. Although businesses seeking to take advantage of Thailand's weak

*Address correspondence to this author at the Faculty of Social Sciences and Humanities, Mahidol University, Thailand;

E-mail: wanaporn.tec@mahidol.ac.th screening and monitoring systems in detecting nominee shareholders are not necessarily members of organized criminal networks, they can easily be well exploited by criminal groups due to their illicit characteristics under Thai law. While the appointment of nominees is legally allowed in many countries (Financial Action Task Force 2018), this practice has created a loophole for criminal groups to manipulate and misuse the system for illegal purposes. Local businesses are among common facilitators that criminal groups seek to establish contacts in order to carry out illegal activities. The study thus aims to examine how interactions among companies using informal nominee shareholders and transnational criminal groups contribute to the growth of transnational crime and their impacts upon the country's economic and social well-being. The study calls for the country's precautionary action to monitor a business practice that can lead to serious consequences, and the need to re-evaluate its current law and policy with regard to business operations in order to come up with proper responses in addressing the problem.

Despite the entry into force of the Convention against Transnational Organized Crime (UNTOC) in 2003 , which serves as a primary instrument to combat 
transnational organized crimes (United Nations Office on Drugs and Crime 2004), the success of its implementation nonetheless rests with individual state legislative measures and mechanisms in monitoring and criminalizing potential criminal activities in connection with transnational crime (Parrish 2012). While a pattern or form of transnational crime can be changing from time to time according to public consumption patterns, lifestyles or other social and cultural contexts (United Nations Office on Drugs and Crime 2013), states are facing more daunting tasks in addressing the challenge as more criminal activities are transcending national borders. With the convention's limitations on preventive measures, a precautionary approach must arguably be taken at a state level. Monitoring and regulating business should be one of the state's primary responsibilities in order to control economic activities that may have a possible connection with transnational organized crime.

\section{LITERATURE REVIEW}

\section{Thailand's Legal Framework on Transnational Organized Crime}

According to the UNTOC, the concept of "transnational organized crime" has been defined in two separate parts. One refers to an organized criminal group, and another refers to the borderless nature of the crime. Although the two separate definitions suggest that while organized criminal groups are not necessarily always involved with transnational crime and vice versa, the force of globalization has essentially made the two terms complementary as the concept of organized crime has changed over time both in the meaning and the territorial scope (Paoli and Beken 2014). The two terms are defined as follows;

"Organized criminal group" shall mean "a structured group of three or more persons, existing for a period of time and acting in concert with the aim of committing one or more serious crimes or offences established in accordance with this Convention, in order to obtain, directly or indirectly, a financial or other material benefit" (UNODC 2004: 5)

"[A]n offence is transnational in nature if: (a) It is committed in more than one State; (b) It is committed in one State but a substantial part of its preparation, planning, direction or control takes place in another State; (c) It is committed in one State but involves an organized criminal group that engages in criminal activities in more than one State; or (d) It is committed in one State but has substantial effects in another State." (UNODC 2004: 6)

In the context of Thailand, several legislations have been adopted in accordance with the UN Convention against Transnational Organized Crime, and pursuant to the policy framework of the country's 20-year national strategic plan (Thailand vision 2037), specifically in the area of security management through integrated mechanisms that call for partnerships among government and private sectors and the civil society (Office of the National and Economic and Social Development Council 2019). The Prevention and Suppression of the Participation in Transnational Criminal Organization Act B.E. 2556 (2013), and the Prevention and Suppression Human Trafficking Act B.E. 2551 (2008), which came to replace the Measures in the Prevention and Suppression of Trafficking in Women and Children Act B.E. 2540 (1997) are among important legislations. Both legislations define "organized criminal group" based on the UNTOC's definition containing the required elements of the number of memberships, time period, objectives and nature of offences punishable by a maximum imprisonment of four years and longer. (Section 3 of the Prevention and Suppression of the Participation in Transnational Criminal Organization Act B.E. 2556 2013; Section 4 of the Prevention and Suppression Human Trafficking Act B.E. 2551 2008) The Prevention and Suppression of the Participation in Transnational Criminal Organization Act of 2013 also further defines "transnational crime" similarly to the UNTOC by taking into account how an offence is committed, and how criminals in other states are being involved such as preparation, planning, direction, support or control of the commission of the offence as well as the substantial effects in another State. (Section 3 of the Prevention and Suppression of the Participation in Transnational Criminal Organization Act B.E. 2556 2013) Align with the domestic and international laws, the Office of National Security Council also defines "transnational crime" more broadly to include the element of an organized criminal group committing a crime punishable in that jurisdiction across borders in order to obtain any kind of benefits in contradiction with the law and morality affecting personal life and security of others, economic and social well-being, and national security. (Secretariat of the House of Representatives 
2019: 2) For the purpose of this research, the study opts to adopt a loose definition of transnational crime pursuant to the Office of National Security Council's definition.

In the assistance of transnational crime suppression and investigation, Section 21 of the Special Case Investigation Act B.E. 2547 (2004) grants special investigative power to the Department of Special Investigation (DSI), especially for the case of serious, complex crimes, or crimes that are transnational and involve criminal groups, or crimes that have substantial impacts on domestic peace, public morality, economic and financial stability, and national security (Special Case Investigation Act B.E. 2547 2004). This legislation hence adopts a broader definition of transnational crime than that of the UNTOC, which provides an additional channel for an investigation and prosecution of a business pattern-seeking to circumvent domestic laws with the likelihood of connecting to transnational crime.

\section{Thailand's Domestic Law on Foreign Business}

Thailand Foreign Business Act B.E. 2542 (1999) (FBA) has been adopted for the purpose of regulating foreign business ownership in the sensitive sectors invested in the country. Pursuant to the legislation, there are three types of businesses that are governed by the law. These are 1) businesses that are strictly

Table 1: Regulated Businesses under the Foreign Business Act B.E. 2542 (1999)

\begin{tabular}{|c|c|c|}
\hline $\begin{array}{c}\text { List 1: Businesses not permitted for } \\
\text { aliens to operate due to special } \\
\text { reasons }\end{array}$ & $\begin{array}{l}\text { List 2: Businesses related to the national } \\
\text { safety or security or affecting arts and } \\
\text { culture, tradition, folk handicraft or natural } \\
\text { resource and environment }\end{array}$ & $\begin{array}{l}\text { List } 3 \text { : Business which Thai national are not } \\
\text { yet ready to compete with foreigners }\end{array}$ \\
\hline $\begin{array}{l}\text { (1) Newspaper business, radio } \\
\text { broadcasting or television station } \\
\text { business } \\
\text { (2) Rice farming, farming or gardening. } \\
\text { (3) Animal farming } \\
\text { (4) Forestry and wood fabrication from } \\
\text { natural forest } \\
\text { (5) Fishery for marine animals in Thai } \\
\text { waters and within Thailand specific } \\
\text { economic zones. } \\
\text { (6) Extraction of Thai herbs. } \\
\text { (7) Trading and auctioning Thai } \\
\text { antiques or national historical objects. } \\
\text { (8) Making or casting Buddha images } \\
\text { and monk alms bowls. } \\
\text { (9) Land trading }\end{array}$ & 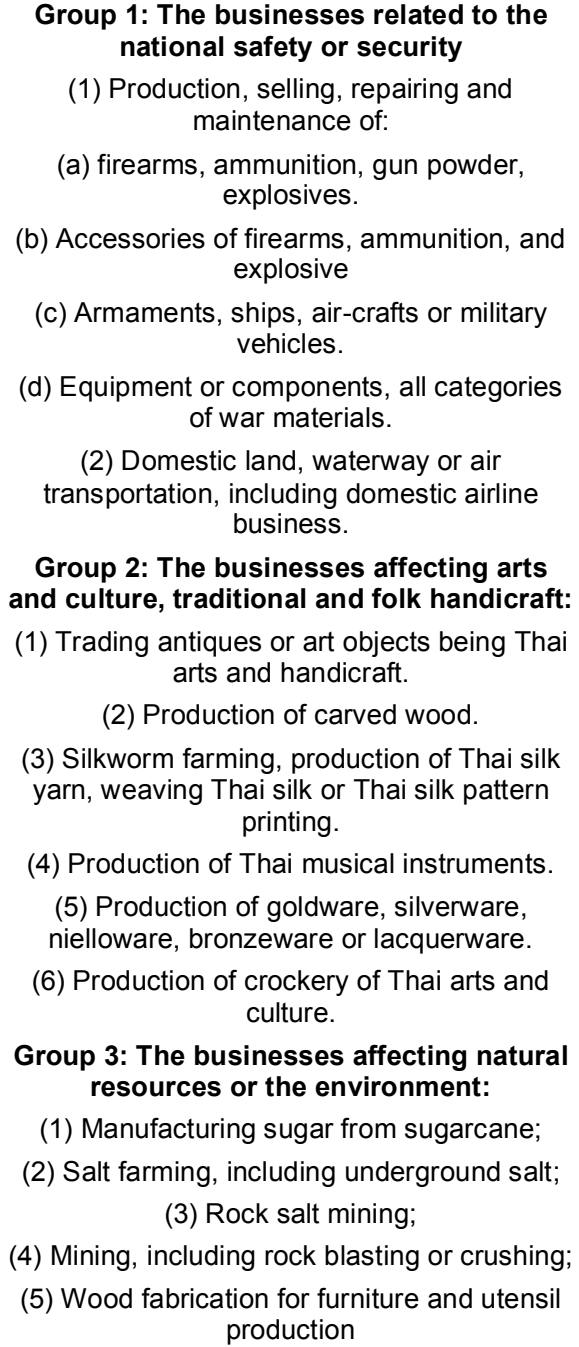 & 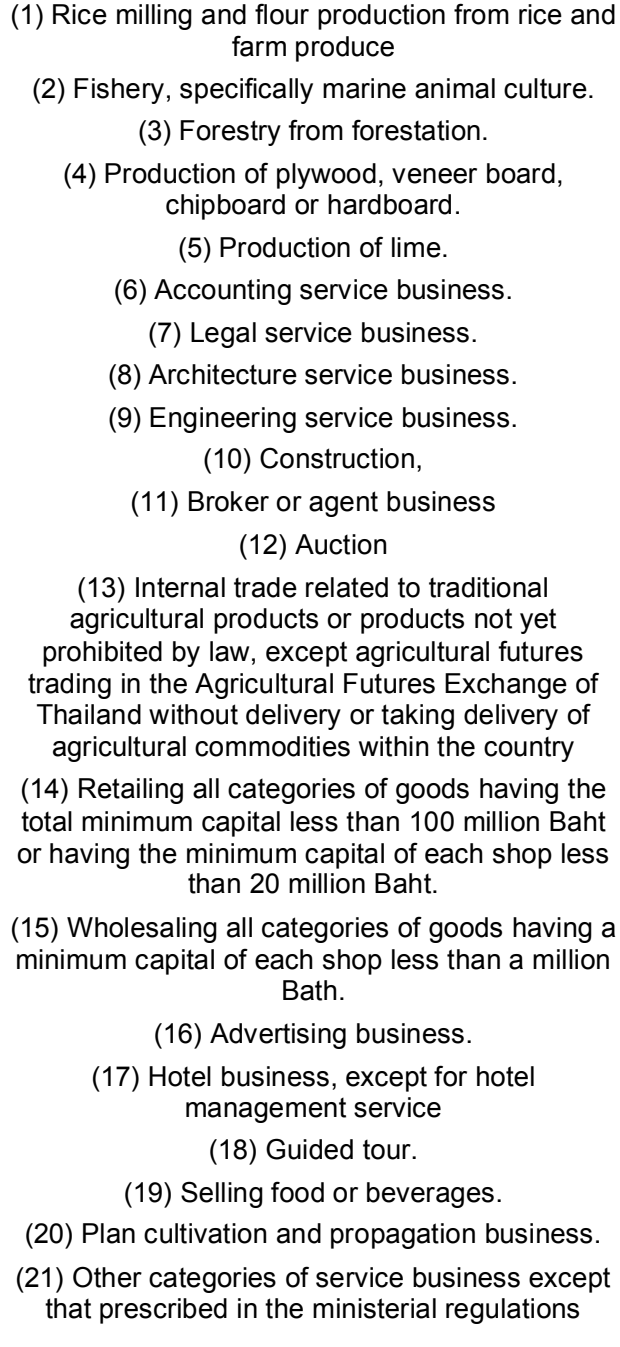 \\
\hline
\end{tabular}


and exclusively reserved for Thai nationals known as List 1 business, 2) businesses that are subject to the cabinet approval, if foreign-owned known as List 2 business, and 3) businesses that are subject to the Director-General of the Commercial Registration Department approval, if foreign-owned, known as List 3 business shown in Table 1 . The law defines a "foreigner" by way of citizenship of a natural person and a juridical person. However, pursuant to Section 4, a juridical person registered in Thailand having the characteristics of either a limited company or a public limited company in which over 50 percent of its equity shares are owned by foreigners will be deemed a foreigner (Foreign Business Act B.E. 2542 1999). The restriction of the law gives rise to a nominee appointment phenomenon, in which foreigners attempting to form a Thai company by securing a Thai national(s) to hold equity shares on behalf of them.

\section{Aliens and the Perpetration of Crime}

The alien conspiracy model has been known as a traditional theory that explains the evolution and development of organized crime. Pursuant to this model, criminal groups such as the Italian or Russian mafia have been formed on the basis of race and ethnicity. These groups of outsiders are believed to accompany their subcultures in the process of relocation. Ethnicity and migration then become primary factors in understanding group membership as part of the migrants' search for physical and mental security (Antonopoulos 2009). Pursuant to the argument, the alien conspiracy model has been understood in the sense that organized criminal groups are formed on the basis of their race and ethnicity, which provides them with a sense of security, especially during difficult periods, like the Great Depression or migration era (Kleemans 2014). Some scholars blamed marginalization and exclusion as the contributing causes of the growth of ethnic-based criminal groups as they struggled to search for a better opportunity in a new, unfamiliar environment (Antonopoulos 2009).

This theory, while being widely-held, is yet subject to criticisms for overlooking other internal factors as the theory only seeks to blame outsiders for their influences on the prevalence of organized crimes in society (Lyman and Potter 2007). Bureaucratic corruption, weak law enforcement and local facilitators are among internal contributing factors that have not sufficiently been dealt with, which involve more than just outsiders (van de Bunt and van der Schoot 2003).
This perspective can well be applied in the context of crime tourism, which refers to crimes committed by tourists or by tourists and foreigners, and may have little to do with migration and marginalization, but are rather based on opportunities and a conducive environment to commit a crime (Cohen 1997). Ethnicity together with a lack of guardianship and protective agencies (laws and institutions charged with enforcement powers) can both play roles in facilitating crime. As different parts of criminal networks face increasing social and geographical barriers, especially in foreign countries in which the environment can be unfamiliar to them, the illegal nature of criminal activities, therefore, requires "...a high degree of mutual trust" among themselves in order to overcome such barriers (Kleemans 2014: 39). From this perspective, certain transnational criminal groups can count on creating a comfort zone for the operation of their criminal activities.

\section{Situation and Opportunity as the Cause of Crime}

Similar to a legitimate business operation, crime also thrives on a favourable environment as opportunities rather than personality traits or biological factors become the offenders' motivations to perpetrate crime (Bullock et al. 2010; von Lampe 2011). Thus, in the context of transnational organized crime, mainstream criminological theories may not provide a sufficient explanation to why ordinary people decide to engage in criminal activities when an opportunity presents itself. The situational approach analysis thus focuses on events and social circumstances instead of offenders as a source of crime (Kleeman, Soudijn and Weenink 2012). The concept builds upon the crime triangle theory with the focus on the opportunity element. At the macro level, certain environment such as weak and ineffective law enforcement, policy gap, a lack of monitoring mechanisms and corruption all play a role in reducing the costs of operating and engaging in illegal activities. At the same time, globalization has provided criminal groups with new tools such as information and communication technology, efficient transportation and logistics, state's open, flexible trade and investment policy to thrive (Keenen 2005; Shelley 2011). These are some of the aspects of the 'nontraditional transnational security threats that evolves around the concept of human security (Kun 2009: 23). Transnational crimes can be perceived as a flip side of the coin of economic development, which relies on certain favorable conditions. At the micro-level, the social environment that provides criminal groups with 
various kinds of facilitators has greatly contributed to the growth of transnational crime. Kruisbergen et al. (2015) found that the element of social opportunity was the primary rationale behind criminal groups' choice of investment. In their study, social ties and abilities to connect with society among criminal groups to ensure their survival rather than the desires to seek profits and power have designated their choice of reinvesting crime proceeds. This is because being able to know someone or trust someone in a highly risky situation is vital to the success of their operation. This opportunitybased analysis thus operates along the line with the rational choice theory, where the perceivable benefits gained (being able to escape criminal prosecution) by criminal groups or those who engage in criminal activities, derive from a favourable environment to commit a crime.

\section{METHODOLOGY}

The study used mixed methods in examining how foreign-controlled disguise companies facilitate transnational criminal activities and their impacts on the country's economic and social development. The quota sampling was the main technique employed in both qualitative and quantitative studies due to the large geographical areas that the study had to cover under a limited time span.

\section{Population}

For the qualitative study, non-probability quota sampling was employed for the conduct of the in-depth interviews and the focus groups. The in-depth interviews were conducted with 38 participants at the administrative level were drawn from private business and key government agencies such as the Chamber of Commerce, the Ministry of Commerce, the Department of Special Investigation, the Royal Thai Police, the Immigration Bureau, and the Office of Attorney General, whereas two focus groups were conducted with 17 officials at the operational level were drawn from the government agencies.

For the quantitative study, the non-probability quota sampling was employed to determine the population size for the minimum of 1,000 participants, who are 18 years old and above from six provinces across five different regions, namely Bangkok, the northern region (Chiang Mai, Chiang Rai), the eastern region (Chantaburi), the southern region (Phuket), and the northeastern region (Maha Sarakam). The selection of the provinces is based on the rate of tourist visits.

\section{Data Collection}

The primary and secondary data were collected through

i. documentary research on relevant domestic laws, and organized crime theories;

ii. conduct of personal in-depth interviews, as this study was undertaken prior to the COVID-19 outbreak, with 8 participants from Chiang Mai, 5 participants from Chiang Rai, 6 participants from Phuket, 5 participants from Maha Sarakam, 5 participants from Chantaburi, and 9 participants from Bangkok;

iii. conduct of two focus groups held in Bangkok and Chiang Mai, of which 10 and 7 officials participated respectively;

iv. conduct public surveys using accidental sampling with 1,160 respondents consisting of 200 respondents from Bangkok, 200 respondents from Maha Sarakam, 200 respondents from Phuket, 200 respondents from Chantaburi, 174 respondents from Chiang Mai, and 186 respondents from Chiang Rai.

\section{Research Tools}

The interview and the focus group questions were designed based on previous studies on the pattern of transnational crime, contributing factors and their impacts in the areas. The questions primarily inquired about the pattern of crime, the problem of nominee shareholder appointment in companies and its connection to transnational crime, contributing factors to such a problem and possible solutions.

The questionnaires contain questions concerning the patterns of illegal businesses in the areas known to the respondents, contributing factors, and their perceptions of the impacts. Respondents were allowed to choose more than once choice. The demographic information consisted of the respondents' age, gender, educational level and occupation.

\section{Data Analysis}

A content analysis was used to analyze the qualitative data in determining themes and concepts. The descriptive statistical analysis was applied in the quantitative study. The data obtained from the questionnaires were analyzed by frequency in percentage (\%). 


\section{Compliance with Ethical Standards}

This study was approved by the Institutional Review Board (IRB), Faculty of Social Sciences and Humanities, Mahidol University, for research ethics in 2019 (Ethics approval number: COA2019/178.2008). The data collected for this research has been obtained with consent from the participants to provide information.

\section{RESULTS AND DISCUSSION}

\section{The Mushroom of Foreign-Owned Disguised Companies and the Perpetration of Crime}

The emergence of legal persons that sought legal loopholes to form national companies by recruiting Thai nationals to hold the company's equity interests, although do not fit the definitions under the laws, or fall under the category of transnational crime per se, can potentially thrive with transnational crime business. Previous studies showed how organized crime groups (OCGs) infiltrated legitimate business through reinvesting in movable and immovable assets such as stocks and companies based on social opportunity structure (Kruisbergen et al. 2015; Savona and Ricardi 2015). The pattern of crime perpetrated by foreignowned or controlled disguised companies found in the study, however, concerns with their potential facilitation to the transnational criminal groups' activities rather than serving as a money-laundering mechanism or a cover-up business.

From the interviews with the senior officers from the Immigration Bureau, some real estate and service sectors that employed Thai nominees to operate their business have been found to provide a platform for conducting organized crime activities. For instance, a call centre scam, in which criminal groups called potential victims abroad while impersonating officials or staff from financial institutions or government agencies in an attempt to extort money from the victims, is wellknown for its operation by foreign criminal groups, who had been admitted into the country on a tourist visa. While the alien conspiracy model has lost its support with regard to the associations between ethnicity and crime (Albanese 2011; Kleemans 2014; McLean and Holligan 2019), the theory may still hold true for certain types of transnational crimes in which perpetrators have a motive to choose a foreign location to be untraceable by their victims. Nonetheless, transnational criminal activity has not simply been found ethnicallybased, but also a collaboration between the locals and foreigners in a conducive environment (Wongthong and Nuntapetch 2018). European national reports also revealed common types of facilitators, which included public officials, legal professionals, lodging-house companies, landlords and hotel owners (van de Bunt and van der Schoot 2003). This type of transnational criminal activity flourishes in the tourist destination provinces like Chiang Mai and Phuket as the criminal groups gain easy access to their resources, such as rental homes and lodges to run their criminal activities, while these accommodations are either illegally owned or operated by disguised foreign-owned companies in violation of the FBA.

While the study of the Financial Action Task Force (FATF) (2018) showed that the misuse of legal persons through an appointment of nominees, such as a shell company without real on-going business activities has been more frequently exploited by transnational criminal groups than a front company that operates legitimate business in order to obscure illicit activities, the use of a front company was also found to facilitate a criminal group in recruiting Thai ladies to become surrogate moms for customers in China for 10,00015,000 US dollars per pregnancy and double the amount for twins, according to the Human Trafficking Suppression Division officials' interview. These customers reached out for commercial surrogacy as a desperate solution for both legitimate and illegitimate purposes, including organ replacement. It has been estimated that at least 50 babies have been sent out to China, the final destination with no records of return since the company, under the cover of a legitimate business, has been operating (Khunsong 2020). Since the entry into force of the Protection of Children Born from Assisted Technology Act. B.E. 2558 (2015), which prohibits commercial surrogacy, and places several restrictions and conditions on the use of assisted technology in conceiving a child due to ethical issues, some of the criminal groups' networks have fled to the neighbouring countries, such as Laos and Cambodia where surrogacy is not regulated, while a recruitment agency is fully operating within the Thai borders (Bangkok Post 2021).

The use of Thai nominee shareholders has not only been found in the registration of the List 3 businesses (service sector), but also in List 1 (exclusively reserved for Thai nationals) pursuant to the FBA. According to the focus group information, illegal agricultural farming run by Thai nominee shareholder companies in the northern provinces was also identified as one of the sectors that took part in the smuggling of migrants. 
These illegal farming businesses in the north oftentimes sought low-paid labourers from illegal migrants from the neighboring countries, like Myanmar and Laos, which are the primary suppliers of cheap labour. Border areas are among vulnerable places where criminal groups seek to smuggle migrants and illicit drugs as these geographical locations offer advantageous conditions for trafficking. (Luong 2020; Norio 2021). Local social networks, relatives and friends were among common facilitators, who assisted in the process of drug shipments in borderland areas (Luong 2020). A case of a banana farm illegally operated by foreigners in Chiang Rai was found to be engaged in hiring illegal migrants as well as providing a shelter for smuggled migrants before supplying them to other parts of the country.

The survey study across five different regions revealed the increased popularity of the shareholder nominee appointment practice, of which number is nearly as high as other types of transnational crime known to the locals. 1160 respondents consisting of 475 males $(40.9 \%)$ and 662 females $(57.1 \%)$ and 23 LGBT (2 \%) identified the top five types of crime known in the areas that either are themselves classified as a transnational crime or may have a possible connection with the transnational crime as shown in Figure 1.

Businesses incorporated under the disguise of a foreign-owned company as a Thai company have recently mushroomed, especially in the tourist destination areas. A statistical report between 20162018 showed the top sectors that employed a nominee shareholder appointment strategy in Chiang Mai, which included real estate, restaurants and housing (Panyaarvudh 2018). These tourist destinations are prone to transnational criminal activities as the areas while attracting investment and foreigners, also provide opportunities and resources for transnational criminal groups to perpetuate their criminal activities (Lemiuex and Felson 2011; Namakorn 2012; Norio 2021).

Thailand's economic policy, which focuses on being a tourist-friendly destination and an investment hub has attracted transnational organized criminal groups as well as normal business groups. The practice of seeking nominee shareholders to form Thai owned companies in regulated sectors has increasingly become prevalent in the tourist areas (Arunmas 2020). Norio (2021) provided an analysis on the appealing of mass tourist resorts to organized criminal groups, which is also based on the concept of social opportunity structure. Tourist destinations can provide criminal groups with resources, facilitators, logistical and social networks better than any other areas. While tourist areas possess many characteristics that facilitate the perpetration of crime such as population diversity and anonymity, rapid flows of financial transactions, viability to hide identity and launder criminal assets (Norio 2021), the fact that these areas foster illegal activities to begin with, which further attract transnational criminal groups to run their operations, can provide an explanation why such an area is a rich source of facilitators. As Thailand's economic structure depends heavily on tourism aside from exports, a growing number of businesses attempting to take advantage of such opportunity

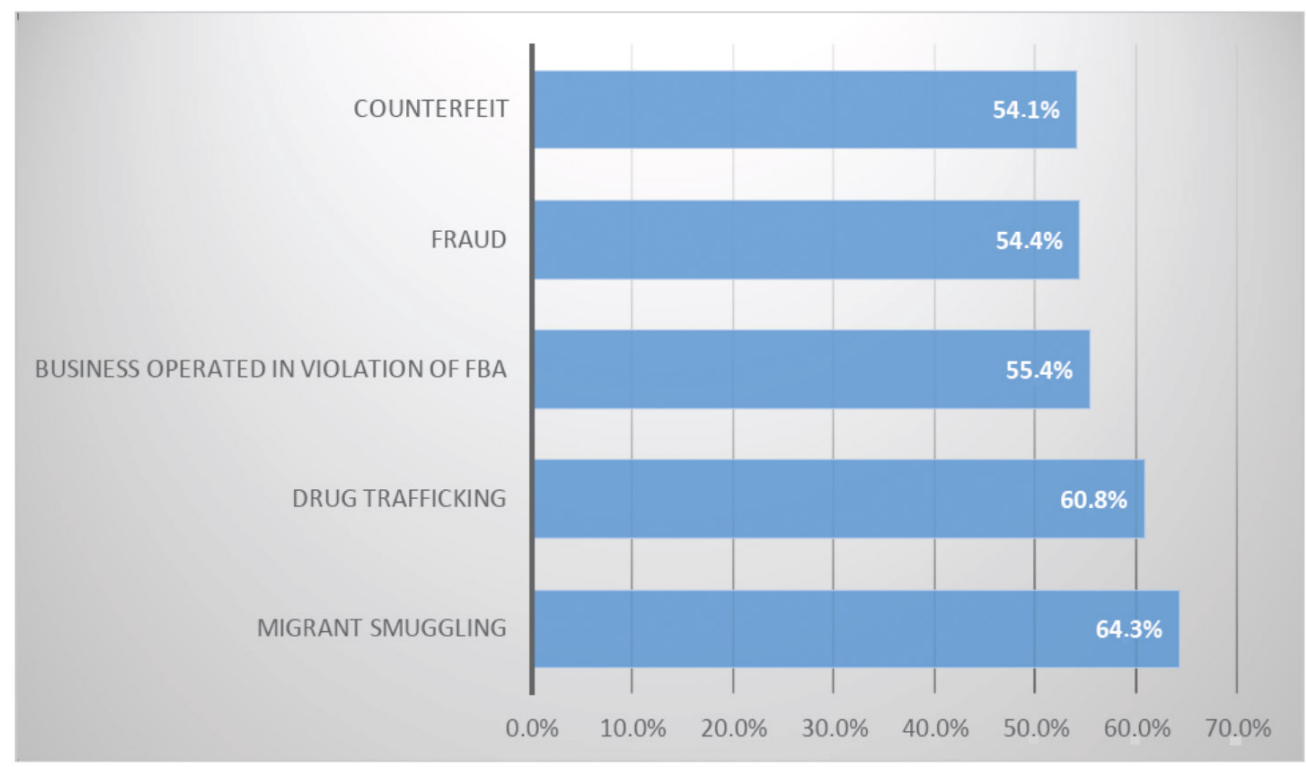

Figure 1: Known Types of Crime in the Areas. 
become involved in unethical and illegal practices. According to the Bangkok Bank's research (2019), the number of tourists continues to grow exponentially from 14.1 million in 2009 to 38.3 million in 2018 accounting for 12.3 percent of its GDP in 2018. The Chinese tourists accounting for 27.5 percent of the total visitors has become the primary driver of the country's economic growth in the area of the tourist industry. In addition, Thailand has long been promoting an economic policy that aims at attracting foreign investment since the 1970 s as part of the third National Economic and Social Development Plan (1972-1976). These efforts take shapes in various forms, including its recent so-called "Thailand Plus", a stimulus package that offers tax incentives together with other initiatives that help facilitate business operations (Medina 2019). Being one of the most popular tourist destinations among the Chinese and the European, Thailand has continued to attract investment from overseas in various tourism-related service sectors such as real estate, restaurants, hotels, condominium (Thailand Board of Investment, 2012). These sectors then become a target for exploitation. The rapid flows of foreign investment in recent years have introduced new forms of unethical and illegal business practices by foreign investment. For instance, the Zero-dollar tourism scheme, in which tourists are lured into buying a cheap tour package, and later pressured into purchasing over-priced products and services from the conspired networked businesses that are disguised as foreign owned or controlled, has caused substantial economic losses to the victims, and serious damages to the country's local economy (Rungsrisawat 2017). Although on the surface, this business practice does not fit any typical category of transnational crime, legal entities adopting this strategy have been found to act as facilitators to criminal groups as they can relate themselves with their illegality characteristics (Financial Action Task Force 2018). The potential risks of the misuse of legal persons through an appointment of informal nominees then become a key vulnerability that calls for states' actions to take precautions as, in the absence of the state's ability to monitor, these grey businesses can serve as a ground for transnational crime to thrive.

\section{Opportunity Gives Rise to Crime}

A situational approach is a convincing analysis in the context of shareholder nominee appointment as the theory sheds light on the opportunity structure and offender convergence settings (Kleeman, Soudijn and Weenink 2012). Van de Bunt and van der Schoot
(2003) reflected on the situational crime prevention theory, which places an emphasis on the control of situational facilitators. Among these factors include a low level of supervision and a low risk of apprehension (van de Bunt and van der Schoot 2003: 20). Facilitating actors must then be analyzed according to their roles. While the abilities to conceal the true ownership and to withhold the information in the registration of a legal entity have been increased by low detections and interventions, the willing participants as shareholder nominees continue to allow criminal cooperation to persist. Facilitating circumstances are thus presented at two levels. The first level is through a lack of effective monitoring mechanisms that give rise to this illegal practice. The second level is through nominee shareholder businesses that provide resources for transnational criminal activities. The typical way for foreigners to circumvent the FBA in order to own and run alien-regulated businesses without obtaining a permit from the authorities is through having the Thai nationals hold equity shares on behalf of them in the amount greater than 50 percent in a company. There are long lists of alien-regulated businesses under various categories as shown in Table 1. Among these include the categories that are directly or potentially related to transnational crime such as the production of firearms, ammunition or maintenance service for military vehicles. Once the company is deemed a Thai national, it can operate List 2 and List 3 businesses without the scrutinization of the authorities.

The absence of effective screening and monitoring mechanisms plays a big part in exacerbating the problem. A practice of seeking Thai nationals as nominee shareholders in foreign companies has been recognized as a type of concealment of beneficiary ownership in a sense that these individuals seek to obscure their ownership of assets while maintaining the power to exercise direct or indirect control over these assets (Financial Action Task Force 2018). Although several cases found in the study have employed the strategy simply to bypass the government regulations, the situation, nevertheless, can potentially be exploited by criminal groups to facilitate their illicit activities. These facilitators, which include lodging companies, as well as other service providers oftentimes, are unaware of the exploitation due to negligence or ignorance (van de Bunt and van der Schoot 2003). The ability to reduce facilitating circumstances of organized crime thus remains a key feature of the situational approach.

Thailand has been struggling to come up with proper measures to control the practice of nominee 
appointment. Failures in the prevention against and monitoring of this business practice reflect on the country's weaknesses in the implementation of its legal framework. According to the senior officers' interviews, the government's limited capacity in screening and monitoring, Thailand investor-friendly policy, the Thai citizens' mindset for personal gains, ineffective law enforcement and administration, and corruption are among the primary contributing factors to the phenomenon. Public officials, legal professionals, landlords, hotel and lodge owners have been known as the most common facilitators in the licit environment (van de Bunt and van der Schoot 2003). With the increasing demands for business registration and a small staff of the Department of Business Development, the administration runs under high pressure. The primary mechanism for screening out hidden foreign-owned businesses is to request all equity shareholders' financial statements as proofs of their revenues that must correspond to their equity shares in the company. However, once the preliminary screening process is complete, the monitoring process is rarely implemented. The Department of Business Development could not provide data as to how many registered companies have concealed their actual beneficial owners.

"It is impossible to track down what they have done with their equity shares after that. It's like we issue a birth certificate for these newborns. But after that, these babies may turn into criminals" (personal communication, September 10, 2019)

While increasing the defensibility of the facilitators can be done in several ways, the European national reports have identified key preventive measures, one of which included improving the efficiency of law enforcement (van de Bunt and van der Schoot 2003). Despite the lack of significant data on the number of foreign-owned disguised companies, the Department of Business Development is, nonetheless, equipped with the power to investigate a situation in which a suspicious case has been detected. One of the mechanisms, which is currently used, is an annual random check targeting a particular industry. Each year businesses that are deemed popular and profitable among foreigners will be selected for the purpose of the inspection. In the past two years, real estate and tourism-related businesses have been the target businesses for the authority's scrutiny. Various Memorandum of Understandings (MOUs) has also been formed among the relevant government agencies such as the Department of Special Investigation (DSI), Thailand Tourism Authorities, Immigration Bureau, and the Ministry of Commerce in the assistance of the suppression of grey businesses that are likely connected with transnational criminal groups. However, in practice, actual coordination among these agencies remains problematic. For instance, while the Department of Business Development faces limited capacity, authority and skills to undertake an investigation, the DSI will only take up a case that involves substantial or drastic impacts at a national scale. Similarly, the Prevention and Suppression of the Participation in Transnational Criminal Organization Act B.E. 2556 (2013) endow the power for a public prosecutor to undertake a co-investigation with the local police, where it is likely that such criminal activities are related to transnational crime. In reality, local police rarely made a case to secure additional assistance from the public prosecutor due to the lack of knowledge.

The survey study also suggested the leading contributing factors to the nominee shareholder phenomenon, which included legal loopholes and policy gap in favour of economic development, ineffective law enforcement or weak enforcement mechanisms, corruption, and tourism promotion policy as shown in Figure 2.

The abuse of legal persons becomes one of the tools for criminal groups to further their goals in the licit environment. Legal loopholes, weak law enforcement, and a lack of effective monitoring mechanisms provide better opportunities for criminal groups and reduce the cost of crime. Reports in European countries such as Finland, Hungary and Italy revealed how businesses are commonly exploited whether to launder money, to cover up illegal activities, or to merely act as facilitators to provide services and assistance to the criminal groups (van de Bunt and van der Schoot 2003). From the perspective of viewing organized crime as a community social institution, these facilitators are social units that perform functions fundamental for daily living and survival for criminal groups (Lyman and Potter 2007) Warren (1973) identified social participation and mutual support as ones of the functions provided by these social units, while community acceptance in which the community locals perceived themselves neither as victims nor accomplices could create a great shelter for criminal groups. Mutual benefits shared among facilitators and criminal groups together with weak law enforcement provided little incentives for these social units to report the crime. The increasing 


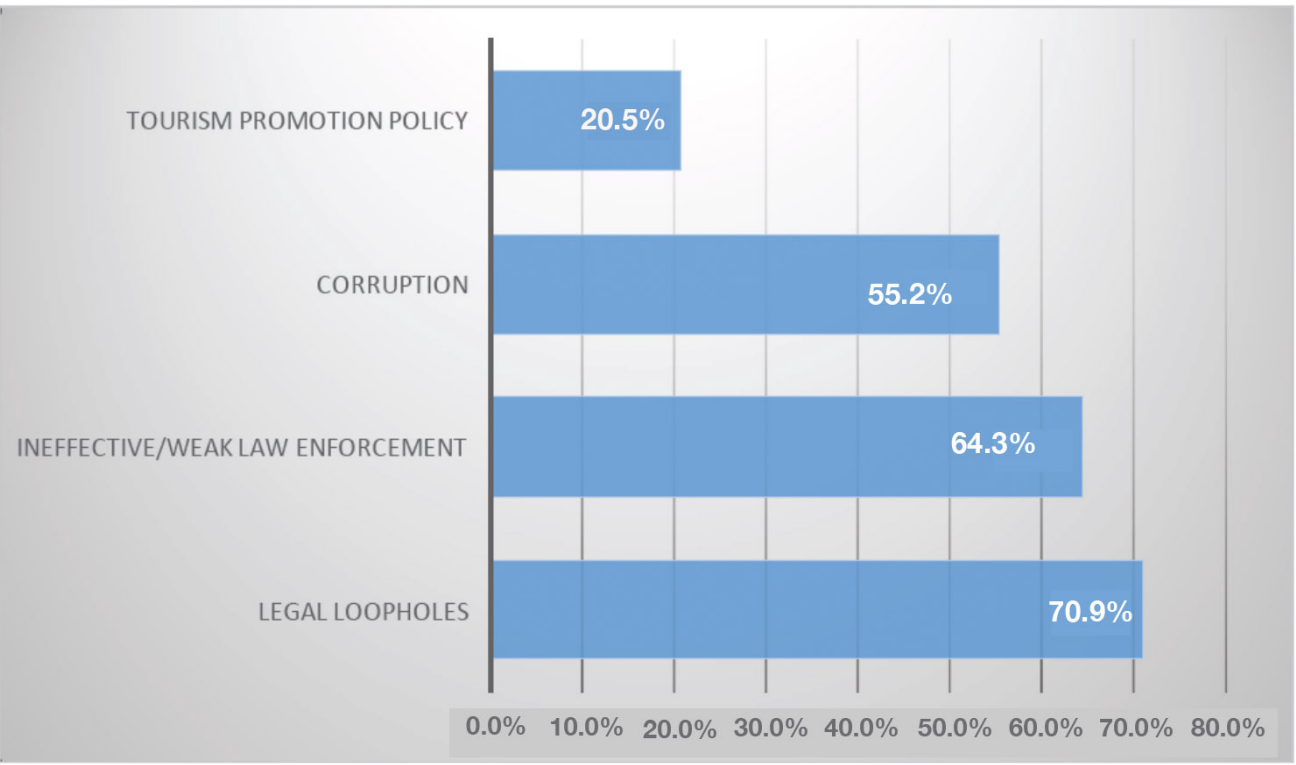

Figure 2: Public Perception on the Contributing Factors.

dependence among them runs the risk of making organized crime "a functional community institution" (Lyman and Potter 2007: 80). Similar to normal legitimate businesses, transnational organized crime also seeks a certain kind of business environment to survive and prosper. These foreign-controlled disguise companies can yield such a condition that poses serious risks socially, economically and politically.

\section{Economic and Social Consequences}

Business practice of using nominee appointment can affect the country economically and socially. In terms of the economic impact, these businesses have created unfair competition by seeking legal loopholes to form a monopoly in the tourism industry, the area upon which the Thai economy depends. The European studies also indicated potential risks of cooperating with criminal groups that could lead to unfair competition within the sector (van de Bunt and van der Schoot 2003). Many of them illegally operate condominiums and rent out residential homes as hotels and resorts involve tax evasion, and without a permit designed to ensure public safety pursuant to the Hotel Act B.E. 2547 (2008). The businesses have generated a vast amount of income that would have been taxable under normal circumstance. With respect to the social impact, these businesses pose threats to the social order and security both at the local and national levels, as some of them invited the smuggling of migrants, while some became a shelter for organized criminal groups (focus group, 11 September 2019). Respondents in the survey study also indicated their leading concerns in terms of economic and social impacts, which were the feelings of life and property insecurity, the loss of economic opportunity, and the diminished capacity of law enforcement agencies in other needed areas. The findings correspond to Wongthong and Nuntapetch's study (2018), which examined the social and economic impacts of transnational crime as well as its facilitators in Pattaya City.

\section{RESULTS AND CONCLUSION}

Businesses employing nominee shareholders practice can be involved in transnational crime in several aspects. They can act as the main vehicle for criminal groups to cover up and divert their proceeds of crime, or organized crime operations. Apart from the conventional understandings, this type of business can simply act as a provider, and is not necessarily part, but can well be exploited by criminal networks. Opportunities provided at the macro (through economic structure, law and policy implementation) and micro (through social ties) levels have significantly contributed to the problem. While criminal groups depend on members and networks to conceal their activities, they also require services and resources of a licit environment.

In terms of the impacts, from an economic perspective, business operating in violation of the FBA may not necessarily be considered as malum in se (evil) as the practice only seeks to circumvent certain process required by the law. Easing business operations can have potentially positive and negative impacts upon the country's social, political and 


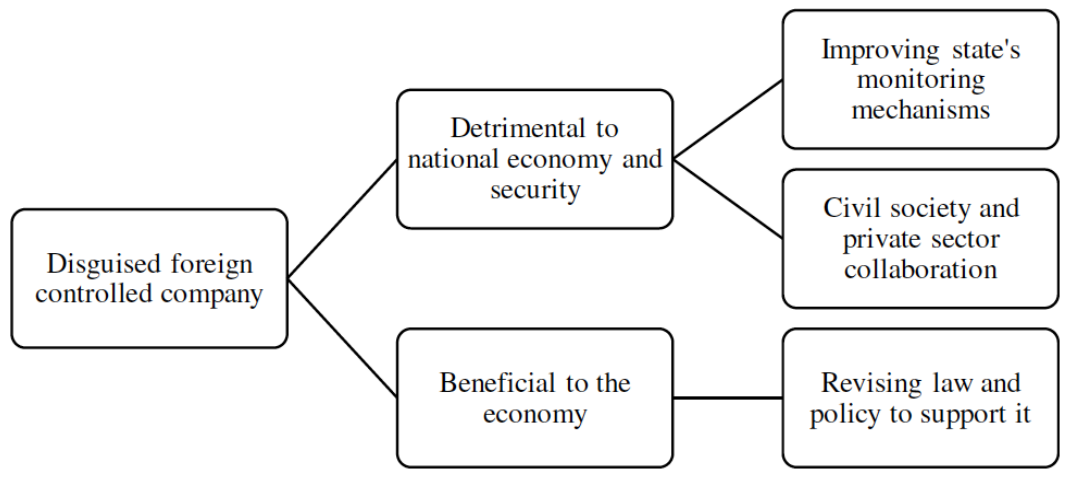

Figure 3: Policy Recommendations.

economic well-being. There are those that are beneficial to the economy, and only employ this method to increase the efficiency of their business operations, and those that are detrimental to the economy, and threaten public morals and safety, and employ this method to stay away from the eye of the law. A policy review is therefore required to improve screening and investigative mechanisms in order to curtail this type of practice.

With this respect, a reconsideration of the country's policy in the area of foreign business registration is needed. The policy recommendations are based on its national Transnational Organized Crime Strategic Plan, specifically the first strategy on empowering state mechanisms and the second strategy on securing outside cooperation (Secretariat of the House of Representatives 2019). These are two primary areas that, if properly promoted, can help support the state's efforts in tackling transnational crime networks.

Align with the first strategy on empowering state mechanisms, amending the FBA and improving the state's monitoring mechanisms are required. As foreign ownership in several types of businesses is restricted under the law, this condition prompts the foreign-owned businesses to seek Thai national nominees to avoid obtaining approval from the state. As the law is regarded as discriminatory in treatment with the primary objective to reserve certain kinds of business exclusively for Thai nationals due to the fear of negative impacts potentially brought by foreign domination (Saypan 2020), rather than to screen out transnational criminal groups' activities, transnational criminal groups have sought this channel to assist their illegal activities. Since nominee shareholder appointment becomes a routine practice for any foreign business that wishes to surmount a hurdle, the law then serves a little function in protecting business sectors against foreign control. Under such a circumstance, removing the restrictions of the businesses that appeared in List 3, which mostly are in the service sector, can be a viable option as it can discourage business owners from unnecessarily withholding information from the government while allowing the state to reallocate its resources to improve their monitoring system in other areas.

With respect to the second strategy on forming outside cooperation and networks, the government should seek allies from the private sector and civil society as they are deemed key facilitators for transnational criminal activities whether negligently or intentionally (van de Bunt and van der Schoot 2003). Improving foreign business' access to information about how to properly conduct a business in the country, raising public awareness of the illegality and ethics of the misrepresentation in the equity interests as well as its adverse consequences can play a key role in reducing the phenomenon. A forum for government authorities and private sectors to share, exchange information and policy, and collectively form resolutions to promote sustainable business should be created. Providing education and sharing information with the public about the patterns of business that have a tendency to connect with a transnational organized crime should also be promoted to protect the public against victimization, or inadvertent participation in the crime.

The findings of the study thus far only reveal how disguised foreign-controlled companies in legitimate businesses can potentially support transnational criminal activities. The current unavailability of government data and statistics on the number of nominee shareholders will continue to pose risks in terms of the abuse of corporate structure. In the process of policy re-evaluation, there is a strong need to further study the trends of businesses engaged in nominee shareholder practice, and their crime patterns 
in connection with transnational criminal groups through previous court cases and investigation reports.

\section{ACKNOWLEDGEMENT}

The authors would like to express our gratitude to the Thailand Research Fund (TRF) for providing this grant (contract number RDG61Q0017) to make this project possible.

\section{REFERENCES}

Antonopoulos, Georgios A. 2009. "Are the 'others' coming?': Evidence on 'alien conspiracy' from three illegal markets in Greece". Crime, Law and Social Change. 52 (5): 475-493. https://doi.org/10.1007/s10611-009-9204-2

Albanese, Jay S. 2011. Transnational Crime and the 21st Century. Oxford: Oxford University Press.

Arunmas, Phusadee. 2020. "Govt cracks down on foreign nominees," Bangkok Post, November 23. Retrieved from https://www.bangkokpost.com/thailand/general/2023991/govt -cracks-down-on-foreign-nominees

Bangkok Bank. 2019. "Tourism: Still a reliable driver of growth?" Retrieved from https://www.bangkokbank.com/en/ International-Banking//media/dc98bd4dd875455299b0c207bf16f2ac.ashx

Bangkok Post. 2021. "Swoop on Surrogacy Network," February 6. Retrieved from https://www.bangkokpost.com/thailand/ general/2063455/swoop-on-surrogacy-network

Bullock, Karen, Clarke, Ron V., and Laycock, Gloria. 2010. Situational Prevention of Organised Crimes. Cullompton, UK: Willan.

Bunt, Henk van de and Schoot, Cathelijne van der. 2003. Prevention of Organized Crime. A situational approach. Boom Juridische uitgevers. DOI: 10.15496/publikation-6612

Cohen, Erik. 1997. Tourism-related Crime: Towards a Sociology of Crime and Tourism. Visions in Leisure and Business 16(1): 4-14.

Department of Business and Development. 2020. The Foreign Business Act B.E. 2542. Retrieved from https://www.dbd.go.th/dbdweb_en/more_news.php?cid=329

Financial Action Task Force. 2018. Concealment of Beneficial Ownership. Paris: Egmont Group.

Keenen, P.J. 2005. "The New Deterrence: Crime and Policy in the Age of Globalization”. Iowa Law Review 91: 505-544.

Khunsong, Preeyapa. 2020. "Thai police to probe surrogacy operation's Chinese links," AP News, February 14. Retrieved from https://apnews.com/article/c6c962949ff6e69fa952 bac07b5bf676

Kleemans, E.R., Soudijn, M.R.J. and Weenink, A.W. 2012. "Organized crime, situational crime prevention and routine activity theory". Trends in Organized Crime. 15: 87-92. https://doi.org/10.1007/s12117-012-9173-1

Kleemans, Edward R. 2014. "Theoretical Perspectives on Organized Crime" Pp. 32-52 in The Oxford Handbook of Organized Crime, edited by Paoli, Letizia. New York: Oxford University Press.

https://doi.org/10.1093/oxfordhb/9780199730445.013.005

Kruisbergen, E. W., Kleeman, E. R. and Kouwenberg, R. F. 2015. "Profitability, Power, or Proximity? Organized Crime Offenders Investing Their Money in Legal Economy" European Journal on Criminal Policy and Research 21(2): 237-256.

https://doi.org/10.1007/s10610-014-9263-5
Kun, Zhai. 2009. "The ASEAN Power." Pp. 21-32 in The Architecture of Security in the Asia-Pacific, edited by Huisken, Ron. ANU Press. https://doi.org/10.22459/ASAP.10.2009.03

Lemiuex, A. and Felson, M. 2011. "Tourist and visitor crime." Pp. 223- 228 in International Crime and Justice, edited by Natarajan, M. New York: Cambridge University Press. https://doi.org/10.1017/CBO9780511762116.035

Luong, Hai Thanh. 2020. "Transnational Crime and its Trends in South-East Asia: A Detailed Narrative in Vietnam". International Journal for Crime, Justice and Social Democracy. 9(2): 88-101. https://doi.org/10.5204/ijcisd.v9i2.1147

Lyman, Michael D. and Potter, Gary W. 2007. Organized Crime. Prentice Hall.

McLean, R. and Holligan, C. 2019. "Alien Conspiracy Theory? Exploring Ethnicity and Drug Supply in Scotland". Deviant Behavior. 41(10): 1244-1257. https://doi.org/10.1080/01639625.2019.1607112

Medina, Ayman Falak. 2019. "Thailand Plus: New Stimulus Package for Foreign Investment." ASEAN Briefing, September 24. Retrieved from https://www.aseanbriefing.com/news/thailandplus-new-stimulus-package-for-foreign-investment/

Murray, K. 2013. "A Square Go: Tackling Organised Crime Where It Doesn't Want to Be Tackled." Journal of Money Laundering Control 16(2): 99-108. https://doi.org/10.1108/13685201311318458

Namakorn, Pornthep. 2012. "The Economic and Social Impact of Transnational Crime in Pattaya City, Thailand". Atlantis Press. 375-377. https://doi.org/10.2991/icpm.2012.57

Norio, E. 2021. "Why are tourist resorts attractive for transnational crime? The case of the Mayan Riviera." Tourism Critiques: Practice and Theory. https://doi.org/10.1108/TRC-10-2020-0019

Office of the National and Economic and Social Development Council. 2019. "National Strategy 2018-2037." Retrieved from http://nscr.nesdb.go.th/wp-content/uploads/2019/10/ National-Strategy-Eng-Final-25-OCT-2019.pdf

Organization for Economic Co-operation and Development. 2001 Behind the Corporate Veil: Using Corporate Entities for Illicit Purposes. OECD Publications Service. https://www.oecd.org/ corporate/ca/43703185.pdf

Panyaarvudh, J. 2018. "Chinese investors making good in Chiang Mai." The Nation, September 2. Retrieved from https://www.nationthailand.com/national/30353559

Paoli, L. and Beken, T.V. 2014. "Organized Crime A Contested Concept." Pp. 13-31 in The Oxford Handbook of Organized Crime, edited by Paoli, Letizia. New York: Oxford University Press. https://doi.org/10.1093/oxfordhb/9780199730445.001.0001

Parrish, Austen L. 2012. "Domestic Responses to Transnational Crime: The Limits of National Law." Criminal Law Forum. 23: 275-293. https://doi.org/10.1007/s10609-012-9185-1

Rungsrisawat, Somdech. 2017. "Zero-Dollar Tour: The Damages of Thai Tourism." Retrieved from http://www.elfms.ssru.ac.th/ somdech ru/file.php/1/1-2560/Research 2017/ZeroDollar_Tour_the_Damages_of_Thai_Tourism.pdf

Savona, Ernesto U. and Ricardi, M. 2015. "From Illegal Markets to Legitimate Businesses: The Portfolio of Organized Crime in Europe." Transcrime: European Commission. Retrieved from https://www.int-comp.org/media/1997/ocp-full-report.pdf

Saypan, Supasit. 2020. "Legal Problems Concerning Nominee Arrangements in Relation to Foreign Business under Thai Laws." Thammasart Business Law Journal. 10: 80-94

Secretariat of the House of Representatives. 2019. "Transnational Crime and the National Security of Thailand." Retrieved from 
https://library2.parliament.go.th/ebook/contentissue/2562/hi2562-012.pdf

Shelley, L. 2011. "The Globalization of Crime." Pp. 223-228 in International Crime and Justice, edited by M. Natarajan. New York: Cambridge University Press. https://doi.org/10.1017/9781108597296.037

Thailand Board of Investment. 2012. "Thailand Strengthens its Bonds with China." Thailand Investment Review 22(5). Retrieved from https://www.boi.go.th/tir/issue/201205_22_5/cover.htm

The Foreign Business Act B.E. 2542. 1999. Government Gazette. Vol. 116, Part 123a, Page 1, dated 4th December B.E. 2542.

The Prevention and Suppression of the Participation in Transnational Criminal Organization Act B.E. 2556 (2013). Government Gazette. Vol. 130, Part 55a, Page 1, dated 26th June B.E. 2556.

The Prevention and Suppression Human Trafficking Act B.E. 2551. 2008. Government Gazette. Vol. 125, Part 29a, Page 28, dated 6th February B.E. 2551.

The Special Case Investigation Act, B.E. 2547. 2004. Government Gazette. Vol. 121, Part 8a, Page 1, dated 19th January B.E. 2547.
United Nations Office on Drugs and Crime. 2013. "Transnational Organized Crime in East Asia and the Pacific." Retrieved from https://www.unodc.org/documents/data-and-analysis/ Studies/TOCTA_EAP_web.pdf

United Nations Office on Drugs and Crime. 2004 "United Nations Convention against Transnational Organized Crime and the Protocols Thereto." Retrieved from https://www.unodc.org/ documents/treaties/UNTOC/Publications/TOC\%20Conventio n/TOCebook-e.pdf

Von Lampe, Klaus. 2011. "The Application of the Framework of Situational Crime Prevention to Organized Crime." Criminology and Criminal Justice 11(2): 145-163. https://doi.org/10.1177/1748895811398459

Warren, Roland, L. 1973. The Community in America. Chicago: Rand McNally.

Wongthong, Leuchai and Nuntapetch, Krisda. 2018. "Transnational Crime and Its Socio-Economic Effects in Pattaya Special Administrative District." The Journal of Faculty of Applied Arts. 11(1): 71-80.

Received on 22-03-2021

https://doi.org/10.6000/1929-4409.2021.10.126

(C) 2021 Chokprajakchat et al.; Licensee Lifescience Global.

This is an open access article licensed under the terms of the Creative Commons Attribution Non-Commercial License (http://creativecommons.org/licenses/by-nc/3.0/) which permits unrestricted, non-commercial use, distribution and reproduction in any medium, provided the work is properly cited. 